\title{
Suitable and available land for settlement development in Cianjur Regency
}

\author{
Nurul Amaliyah Tanjung ${ }^{\mathrm{a}}$, Ernan Rustiadi ${ }^{\mathrm{a}}{ }^{\mathrm{b}}$, Widiatmaka $^{\mathrm{a}}$ \\ ${ }^{a}$ Study Program of Regional Planning Science, Department of Soil Science and Land Resource, Faculty of Agriculture, IPB \\ University, 16680, Indonesia \\ ${ }^{\mathrm{b}}$ Center for Regional System Analysis, Planning and Development (CRESTPENT/P4W) IPB University, 16680, Indonesia
}

\section{Article Info:}

Received: 13 - 10 - 2021

Accepted: 15 - 12 - 2021

\section{Keywords:}

AHP, land availability, land

suitability, MCE, settlement

Corresponding Author:

Nurul Amaliyah Tanjung

Graduate School of IPB

University,

Tel. +62 82384473138

Email:

nurulamaliyahtanjung@gmail.co $\mathrm{m}$

\begin{abstract}
A merging of Jakarta and Bandung metropolitans influences the development of their areas, especially Northern of Cianjur Regency. Consequently, people are migrating to the cities caused an increasing population. Data showed that out-migration in Northern Cianjur is ten times higher (1 768 people) than in Southern Cianjur (182 people). It leads to experiencing uncontrolled advancement and arising problems, like the raising land demand for settlement development, but the land is limited. Therefore, this research aimed to address these particularities by modeling suitable and available land for settlement development in Cianjur Regency. Multi-criteria evaluation (MCE) and geographical information system (GIS) were collaborated to define the suitability criteria. Pairwise comparison was employed to set the criteria's weight. Spatial Plan and LP2B were carried out as limiting factors. Results showed that the most crucial consideration came from the disaster. The suitability classes in Cianjur regency are: highly suitable 36\%; Suitable 7\%; Marginally suitable 44\%; and Not suitable 14\%. In 2018, 85\% of the land was available for settlement. However, it decreases to $2 \%$ in 2030 caused by land conversion for settlement use. Stakeholders' preferences in determining the most critical criteria for land suitability are different. Therefore, it plays a crucial role in the next Cianjur's settlement development planning. Implementing the Spatial Plan can minimize environmental problems such as land conversion. In addition, regarding the new regulation on $L P 2 B$, the spatial plan has to be updated to synchronize the plan between Spatial Plan and LP2B.
\end{abstract}

How to cite (CSE Style $8^{\text {th }}$ Edition):

Tanjung NA, Rustiadi E, Widiatmaka. 2021. Suitable and available land for settlement development in Cianjur Regency. JPSL 11(4): 550-566. http://dx.doi.org/10.29244/jpsl.11.4.550-566.

\section{INTRODUCTION}

The term megacity has been defined to describe the adjoining of metropolitan. Large cities with their surrounding suburbs as a spatial contiguous of urban agglomeration as well (Rustiadi et al., 2021. The changing of demographical, spatial, and economic conditions in the inter-metropolitan corridor is mainly caused by the increasing population and the massive activities in the metropolis regions. Research by Chairunnisa et al (2017) resulted within 15 years, the year 2000 to 2015, the massive decrease on land in Cianjur Regency is happening on the forest land and paddy field. It decreased $55.747 \mathrm{~km}^{2}$ and $54.384 \mathrm{~km}^{2}$, respectively. A study by Ingram (2014) found the financial strength of metropolitan is that they produce spatially integrated markets, housing, labor, etc. It enhances efficiencies in production and consumption at the metropolitan level. As several 
metropolitans continue to grow, then the problems after problems arise, such as demand for housing and settlements (Gayen and Saha, 2018; Steinberg, 2018; Subiyanto et al., 2021).

Cianjur is one of the regions that experience the same thing as The Megapolis of Jakarta-Bandung. It is called the JBMUR, Jakarta-Bandung Mega Urban Region. The massive growth of the people and people's demand for land brings development advantages and problems simultaneously. It can be seen from the increasing economic activity of the urban community and the surrounding area, leading to physical changes. One of the physical changes of land is the occurrence of changes in land use. Such a situation may affect positively because it increases settlements and community welfare (Madurika dan Hemakumara, 2015). But at the same time, the changes in land-use will also reduce agricultural land. As a result, the production of agricultural products would be decreasing as well. Such a phenomenon will harm community food security and the economy of farmers (Ruswandi et al., 2017; Hudalah et al., 2019).

An increasing economic activity encompasses people from other regions to migrate to Cianjur Regency for better opportunities (Harahap, 2013; Sadyohutomo, 2009). The study report on the expansion of Cipanas, northern Cianjur is almost $60 \%$ of the PAD of Cianjur Regency. Another study by Tanjung et al., 2021 showed that out-migration in Northern Cianjur is ten times higher (1 768 people) than in Southern Cianjur (182 people). Therefore, Cianjur's economic development is followed by population growth and settlement demand. To maintain the survival community, the need for those facilities must be fulfilled (Kadriansari et al., 2017). In addition, infrastructure can support economic activities and community activities. Fulfilling the demand for land for settlements is increasing. Meanwhile, the land is limited. Thus, efficient service on the land ((Asfari et al., 2017; Asoka et al., 2013; Kadriansari et al., 2017). In addition, Cianjur District Mission states that infrastructure development must be environment-based. Therefore, this research considers the land suitability and availability as the environment-based to use the land efficiently.

The land supply and demand analysis in Cianjur Regency has previously been carried out by Tanjung $e t$ al. (2021) using a System Dynamics Model. However, modeling using system dynamics has shortcomings in spatial or field conditions. Therefore, the model cannot predict which areas will experience changes, and the model can only expect the amount of land demand for the measured variables. Therefore, this study addresses this limitation by modeling land utilization for settlement in Cianjur Regency. Thus, this research will provide an overview and projection of land use changes for settlements in Cianjur Regency based on the land suitability and availability. It is intended to realize the vision and mission of making Cianjur Regency a developed district. Based on such consideration, this study aims to identify land suitability for settlements in Cianjur Regency and delineate land availability for settlements in Cianjur Regency.

\section{METHODOLOGY}

\section{Time and Research Location}

The research started in January 2021 and finished in September 2021. Cianjur Regency has been chosen as a case study for this research because it is one of many regions between Jabodetabek Metropolitan and Bandung Raya Metropolitan (Figure 1). Demographically, Cianjur's population in 2018 was 2256589 people, 1160520 were male, and 1096069 were female. Therefore, the male population was dominant. Cianjur Regency consists of 32 sub-districts and 434 villages, with a total area is $3614.35 \mathrm{~km}^{2}$.

\section{Data Collection}

Data used in this study are: Cianjur Regency in number year 2017, 2018, 2019 (PDF). Village potential of Cianjur Regency (xlsx). Spatial planning of Cianjur Regency year 2011-2031 (shapefile), Landuse of Cianjur Regency 2018 (shapefile), LP2B of Cianjur Regency year 2019 (shapefile). Landslide and flood risk 2019 (shapefile). Those data are collected from Statistic's Cianjur (Badan Pusat Statistik Kabupaten Cianjur), Center for Research and Development of Agricultural Land Resources (Balai Besar Penelitian dan Pengembangan Sumberdaya Lahan Pertanian), Public Works and Public Housing Agency of Cianjur (Dinas 
Pekerjaan Umum dan Perumahan Rakyat Kabupaten Cianjur) and InaRisk by Indonesian National Board for Disaster Management (Badan Nasional Penanggulangan Bencana Indonesia).

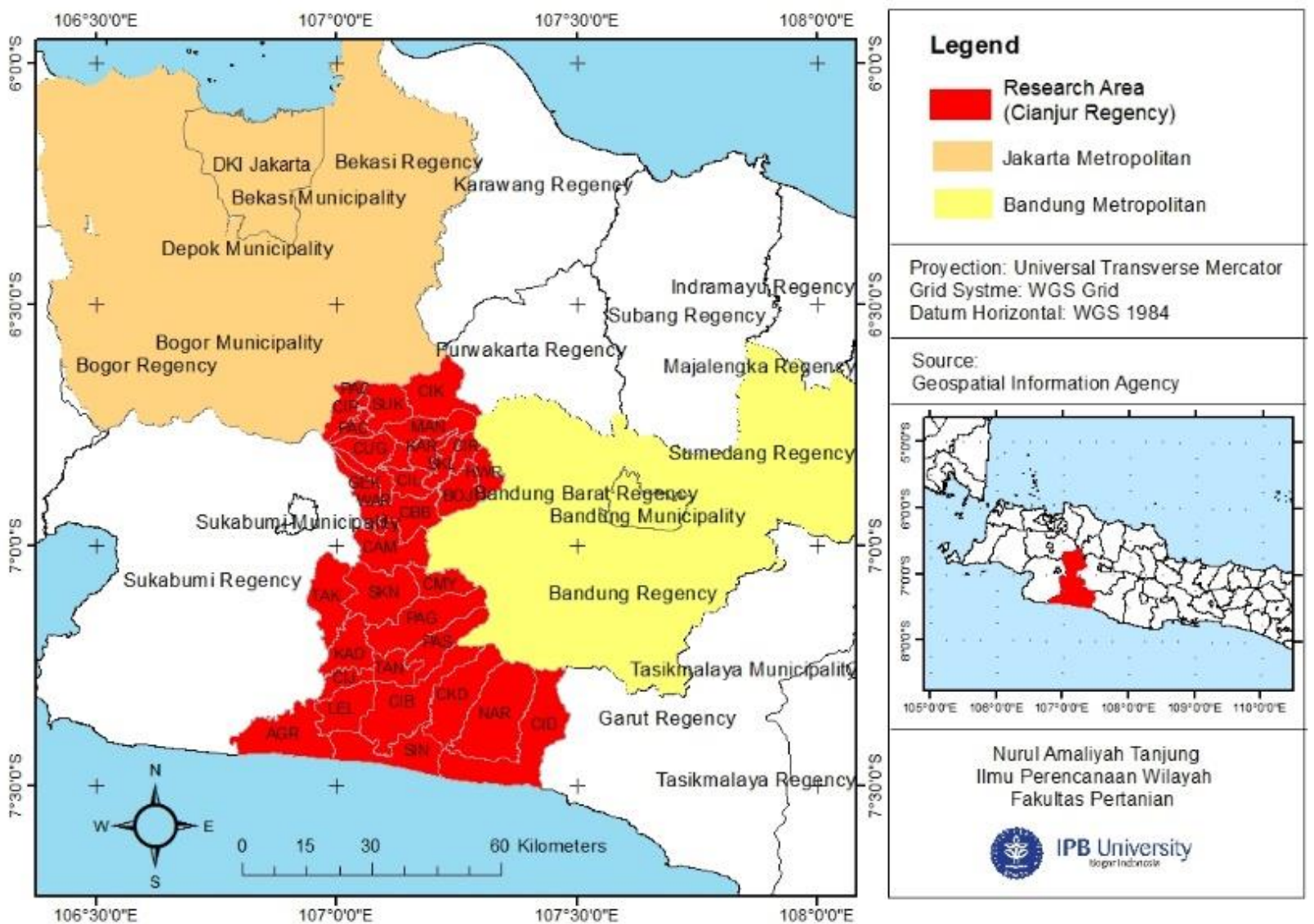

Figure 1 Research area

\section{Data Analysis Method}

\section{Land Suitability}

Land suitability analysis began with selecting criteria that can represent the suitability of land for settlement. This methodology is called Multi-Criteria Evaluation (MCE). For spatial analysis, MCE generally collaborated with Geographical Information System (GIS). This methodology is familiar among planners. Then, pairwise comparison sets the weight of each measure to see which criteria are the most important and which are the least important. Land suitability for settlement in Cianjur Regency is considered four aspects, which are: (1) physical; (2) accessibility; (3) conservation, and; (4) disaster. Each consideration has sub-criteria that can be seen in Table 1 .

Table 1 Criteria, sub-criteria, evaluation scale, and value for land suitability

\begin{tabular}{ccc}
\hline Criteria & Sub- Criteria & References \\
\hline & $0 \%-3 \%$ & \\
$4 \%-8 \%$ & \\
Slope & $9 \%-15 \%$ & SNI 03-1733-2004 About residential neighborhood planning \\
& $16 \%-25 \%$ & procedures \\
& $26 \%-40 \%$ & Madurika and Hemakumara, 2015 \\
& $>40 \%$ & \\
\hline
\end{tabular}




\begin{tabular}{|c|c|c|}
\hline Criteria & Sub- Criteria & References \\
\hline Soil type & $\begin{array}{c}\text { Alluvial } \\
\text { Latosol } \\
\text { Mediterranean } \\
\text { Red-yellow podzolic } \\
\text { Andosol } \\
\text { Grumosol } \\
\text { Regosol }\end{array}$ & $\begin{array}{c}\text { SK No:837/Kpts/Um/11/1980 about Criteria and Procedure } \\
\text { for Determination of Protected Areas and } \\
\text { Decree of the Minister of the Agriculture } \\
\text { No.837/KPTS/Um/11/1980 }\end{array}$ \\
\hline Soil texture & $\begin{array}{l}\text { Slightly coarse } \\
\text { Slightly fine } \\
\text { Smooth }\end{array}$ & Umar et al., 2017 \\
\hline Solum depth & $\begin{array}{l}\text { Shallow }(<50 \mathrm{~cm}) \\
\text { Slightly deep }(51-90 \\
\mathrm{cm}) \\
\text { Deep }(>90 \mathrm{~cm})\end{array}$ & Umar et al., 2017 \\
\hline Drainage & $\begin{array}{l}\text { Very Good, good } \\
\text { Slightly obstructed } \\
\text { Obstructed }\end{array}$ & Umar et al., 2017 \\
\hline $\begin{array}{l}\text { Distance from } \\
\text { roads }\end{array}$ & $\begin{array}{l}0-100 \text { meters } \\
101-750 \text { meters } \\
>750 \text { meters }\end{array}$ & Hasan et al., 2017 \\
\hline $\begin{array}{l}\text { Distance from } \\
\text { river }\end{array}$ & $\begin{array}{l}0-100 \text { meters } \\
101-750 \text { meters } \\
>750 \text { meters }\end{array}$ & $\begin{array}{l}\text { Indonesia's Government Regulation No. 38/2011 about The } \\
\text { River. } \\
\text { Subiyanto et al., } 2021\end{array}$ \\
\hline $\begin{array}{l}\text { Distance from } \\
\text { forest area }\end{array}$ & $\begin{array}{l}>500 \text { meter } \\
101-500 \text { meter } \\
0-100 \text { meter }\end{array}$ & $\begin{array}{c}\text { Government regulation and public works No. } \\
\text { 05/PRT/M/20008 about Regulation for the provision and } \\
\text { use of green open sapace in the urban areas. } \\
\text { Gayen and Saha, } 2018\end{array}$ \\
\hline Flood risk & $\begin{array}{c}<0 \text { (No risk) } \\
0-0.3 \text { (Low risk) } \\
0.3-0.6 \text { (Medium risk) } \\
0.6-1 \text { (High risk) }\end{array}$ & Umar et al., 2017 \\
\hline Landslide risk & $\begin{array}{c}<0 \text { (No risk) } \\
0-0.3 \text { (Low risk) } \\
0.3-0.6 \text { (Medium risk) } \\
0.6-1 \text { (High risk) }\end{array}$ & Umar et al., 2017 \\
\hline
\end{tabular}

Comparison is taken from actual measurements or the fundamental scale, reflecting the relative strength measurement of preferences (Saaty, 1987). As the primary use of pairwise comparison is to define the "weight" of each criterion, there are four steps things to do, are (1) defining the problem; (2) Structuring the decision hierarchy from the top with the goal, criteria, sub-criteria, and alternative; (3) constructing a set of pairwise comparison matrices, and; (4) using the priorities from the comparisons to weigh the priorities (Madurika dan Hemakumara, 2015; Saaty, 2008):

1. Defining the Problem

2. Structuring the decision hierarchy (Figure 2)

3. Constructing a set of pairwise comparison matrices (Table 2) 


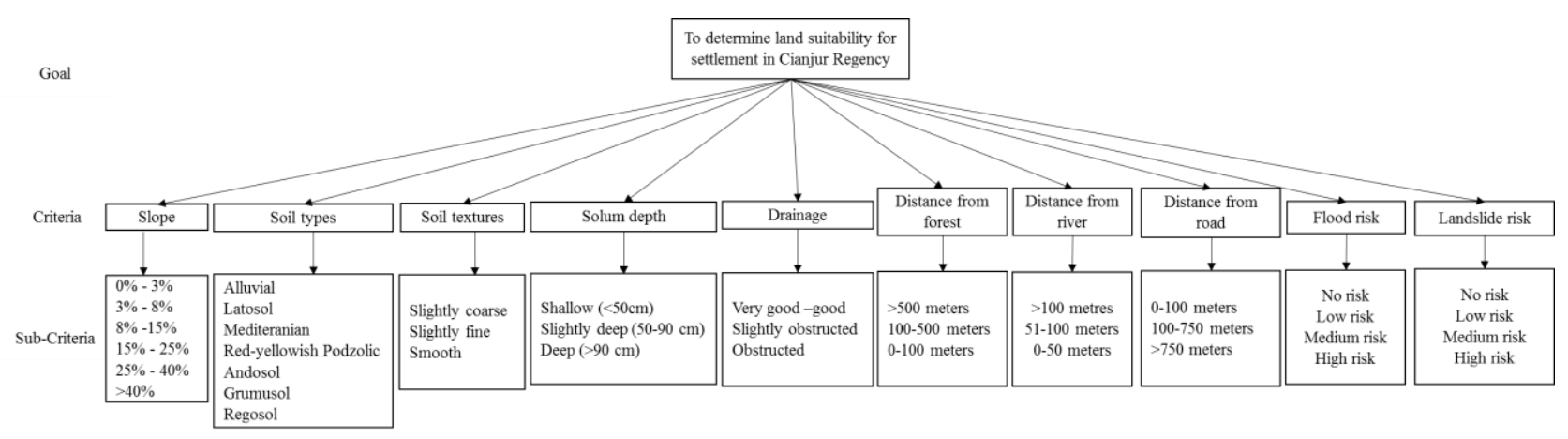

Figure 2 Hierarchy on land suitability analysis

Table 1 The AHP pairwise comparison scale

\begin{tabular}{cl}
\hline Value of $\mathrm{a}_{\mathrm{xy}}$ & \\
\hline 1 & $\mathrm{x}$ and y are equally important \\
3 & $\mathrm{x}$ is slightly more important than $\mathrm{y}$ \\
5 & $\mathrm{x}$ is more important than $\mathrm{y}$ \\
7 & $\mathrm{x}$ is strongly more important than $\mathrm{y}$ \\
9 & $\mathrm{x}$ is absolutely more important than $\mathrm{y}$ \\
$2,4,6,8$ & Intermediate values between the two adjacent judgments \\
\hline
\end{tabular}

The criteria of each level are compared pairwise concerning specific criterion in the immediate upper level. The following judgment matrix is used to calculate the priorities of the criteria:

$$
A=\left[\begin{array}{llll}
a_{11} & a_{12} & \ldots & a_{1 n} \\
a_{21} & a_{22} & \ldots & a_{2 n} \\
& & & \\
\ldots & \ldots & \ldots & a_{n n} \\
a_{n 1} & a_{n 2} & &
\end{array}\right]
$$

Where $\mathrm{a}_{11}$ is the preference of score comparison between sub-criteria 1 and itself. Where axy is the preference of score comparison between criterion $\mathrm{x}$ and criterion $\mathrm{y}$. the pairwise comparison matrix is reciprocal, meaning that the value above the diagonal is the inverse of the value below the diagonal and the diagonal component of the matrix becomes the separator (Panuju, 2016).

4. Using the priorities from the comparisons to weigh the priorities

The prioritizing of the criteria can be estimated by finding the principal eigenvector $\mathbf{W}$ of matrix $\mathbf{A}$. when vector $\mathbf{W}$ is normalized, It becomes the vector of priorities of the criteria of one level concerning the upper level.

$$
A W=\lambda_{\max } W
$$

Where $\lambda_{\max }$ is the maximum eigenvalue of the matrix A. The decision-making parameter that needs to be assessed is the consistency of choices based on pairwise comparisons. The consistency value is calculated using the consistency index parameter obtained through the following equation:

$$
C I=\frac{\lambda_{\max }-\mathrm{n}}{n-1}
$$

Where $\mathbf{C I}$ is the consistency index, is the most prominent feature root of the pairwise comparison matrix, and $\mathbf{n}$ is the order of the comparison matrix. AHP allows inconsistency, but provides a measure of the inconsistency in each set of judgments. The consistency ratio (CR) which is defined as: 


$$
\mathrm{CR}=\frac{C I}{R I}
$$

Where CI is the consistency Index and RI is the Random Index. RI values depend $\mathbf{n}$. it can be seen on Table 3. A consistency ratio of $0.1(10 \%)$ or less is considered acceptable. If the value is higher, the judgments may not be reliable and should be elicited again. Random index for ten (n) variables is (RI): 1.49 (Table 3). Once the weighted values of the criteria are available, then the essential sub-criteria among others for land suitability is also known. A forward step is to calculate a score of each sub-criterion on ArcGis. The score of each creation is done by multiplying the weight of the criteria by the value. The value of each sub-criteria was referred from a similar study. It has to be noted that there is no specific software used during this analysis. Yet, it is available for AHP, such as Expert Choice, Super Decision, etc.

Table 2 The average consistencies of random matrices

\begin{tabular}{|c|c|c|c|c|c|c|c|c|c|c|c|c|c|c|c|c|c|}
\hline n & 1 & 2 & 3 & 4 & 5 & 6 & 7 & 8 & 9 & 10 & 11 & 12 & 13 & 14 & 15 & 11 & 12 \\
\hline $\mathbf{R I}$ & 0 & 0 & 0.58 & 1.90 & 1.12 & 1.24 & 1.32 & 1.41 & 1.45 & 1.49 & 1.51 & 1.48 & 1.56 & 1.57 & 1.59 & 1.51 & 1.48 \\
\hline
\end{tabular}

After gathering the scores of each creation on each thematic map, the "score" is inserted into the "attribute table" on thematic maps for each criterion. The subsequent analysis is by overlapping those thematic and its attribute into one shape file map using a tool called "intersect" on ArcGIS. The result would be the score of each polygon. It ranges from the least score to the highest score. Equation 1 is used to determine the zoning of land suitability for settlements. Where $\boldsymbol{I}$ is a distance between intervals. $\mathbf{c}$ is the number of the highest score. $\mathbf{b}$ is the number of the lowest score. $\mathbf{k}$ is the number of suitability classes that are wanted. The output is a map named land suitability map.

$$
I=\frac{\mathrm{c}-\mathrm{b}}{\mathrm{k}}
$$

\section{Delineation of Land Availability for Settlements in Cianjur Regency}

It is necessary to delineate the available land for building new settlements in 2030. In this research, land availability analysis has been done three steps:

1. Land Availability in 2018. First is to see the availability of the land in the current situation, which is 2018. The analysis used is overlapping of land suitability map and land-use existing (2018), using a tool called "intersect".

2. Potential available land in 2030. Second, availability is called "potential available land for settlement in 2030". It has been done by overlapping land availability in 2018 with the Spatial Plan of the Cianjur Regency.

3. Land Availability in 2030. Third, potential available land for settlement in 2030, overlapping with the LP2B to get the Land availability in 2030 .

\begin{tabular}{|c|c|c|c|c|c|c|c|}
\hline Suitability & $\mathrm{C}$ & LP2B & $\mathrm{C}$ & Land-use 2018 & $\mathrm{C}$ & RTRW 2030 & $\mathrm{C}$ \\
\hline \multirow{2}{*}{ Highly suitable } & \multirow{2}{*}{1} & \multirow{2}{*}{ Irrigated paddy field } & \multirow{2}{*}{0} & Agriculture & 1 & Agriculture & 0 \\
\hline & & & & Open field & 1 & Forest conservation & 0 \\
\hline \multirow[t]{2}{*}{ Suitable } & \multirow[t]{2}{*}{1} & \multirow[t]{2}{*}{ Tidal field } & \multirow[t]{2}{*}{0} & Others & 1 & $\begin{array}{l}\text { Limited forest } \\
\text { Production }\end{array}$ & 0 \\
\hline & & & & Plantation & 1 & Paddy field & 0 \\
\hline \multirow{2}{*}{ Marginally suitable } & \multirow{2}{*}{1} & \multirow{2}{*}{ Rain fed paddy field } & & Settlement & 0 & Plantation & 0 \\
\hline & & & 0 & Water body & 1 & Protected forest & 0 \\
\hline \multirow{2}{*}{ Not suitable } & \multirow{2}{*}{0} & & & Paddy field & 1 & Production forest & 0 \\
\hline & & & & Forest & 1 & Settlement & 1 \\
\hline
\end{tabular}

Table 3 Land code $(\mathrm{C})$ 
The code has been determined on each land use (Table 4). It is used to decide between two maps when overlapping thematic maps. The " 1 " means the decision is "available," while " 0 " means that the decision is "Not available". Matrix decision of land availability between thematic maps can be seen in Table 5. This matrix allows the researcher to make a decision when overlapping thematic maps.

Table 4 Decision matrix of land availability

\begin{tabular}{ccc}
\hline Thematic map "A" & Thematic map "B" & Decision (land Availability) \\
\hline 1 & 1 & 1 \\
1 & 0 & 0 \\
0 & 1 & 0 \\
0 & 0 & 0 \\
\hline
\end{tabular}

\section{RESULT AND DISCUSSION}

\section{Land Suitability for Settlement in Cianjur Regency}

\section{Physical Consideration}

The land has different primary physical conditions from one to another due to geological differences. The physical condition sometimes can be an advantage for development. The fertile soil, sufficient natural resources, sloping and stable morphology are supporting factors for development. Meanwhile, steep and unstable morphology, disaster-prone areas, and infertile soils are the barriers to development. In this study, the physical consideration consists of five sub-criteria, which are: (a) slope; (b) soil types; (c) soil texture; (d) solum depth, and; (e) drainage.

Slope determines the difficulty level of settlement construction work. The gentler the slope, the easier it is to build the housing, and vice versa. The steeper the slope, the more difficult it is to build housing. The slope analysis for settlement suitability refers to Indonesian National Standard 03-1733-2004 about Procedures for Planning Residential Neighborhoods in Urban Areas. Figure 3 shows that most of the slope in Cianjur Regency is $26-40 \%$ (not suitable), with a total area of $1258 \mathrm{~km}^{2}$. It spread mainly in the Northwest, center, and Southeast Cianjur, like Naringgul sub-districts. The slope of more than $40 \%$ (not suitable) is the slightest slope among others. It has $323 \mathrm{~km}^{2}$ of land It spread mainly in the northeast Cianjur, Cikadu Sub-districts, and the South-east Cianjur, Cidaun Sub-district.

Soils are different in the areas, depending on their origins, compositions, locations, geological histories, and many other factors. It has a high correlation with sensitivity of erosion and construction. Referring to the SK No:837/Kpts/Um/11/1980 about criteria and procedure for determination of protected areas, alluvial, glei planosol grey hydro morph, and literita groundwater are solid which are not sensitive to erosion. Meanwhile, Regosol, Litosol Organosol, and Rezina are types of soil which susceptible to erosion. The more sensitive the soil to erosion, the less suitable land suitability for settlement.

There are seven types of Soil found in Cianjur Regency. Figure 4 shows Latosol was found is the majority, with the total area $1847 \mathrm{~km}^{2}(51 \%)$. It spread over the northern and southern Cianjur, but mainly bordering on the south beach. Then it can be said that Cianjur has a high risk of erosion. Soil also correlated the with construction as the building foundation and as the material for making the brick cement etc. Good soil for infrastructure has: balanced chemistry and neutral $\mathrm{pH}$ so that building materials are not corroded; stability through wetting and drying cycles so that expanding soil does not crack roads or foundations; strength under pressure so that the weight of the building does not cause it to sink into the ground, and ability to capture precipitation so that runoff and erosion do not damage structures (Hardiyatmo, 2013; Isao and Hemanta, 2011).

Soil is composed of small particles. There are three categories for particles, sand, silt and clay. It calls as the Soil Separates. The three groups are divide by their size particle size. Clay particles are the smallest, Sands are the largest, and Silts are in the middle. The majority of the soil texture in Cianjur Regency is smooth 3395 $\mathrm{km}^{2}$ (Figure 5). The suitable texture of the soil for building settlement is slightly coarse and slightly fine. 556 
Therefore, Cianjur Regency is not likely suitable for building the settlement, from a soil texture perspective. Soil texture also correlated with the compaction technique which used for contracting the foundation of the building. On the field the granular soil, like sand and pebbles is are relatively easy to compact. Because this material is able to provide high shear strength with little change in the volume of the compacted and also its high permeability can sometimes be detrimental and beneficial.

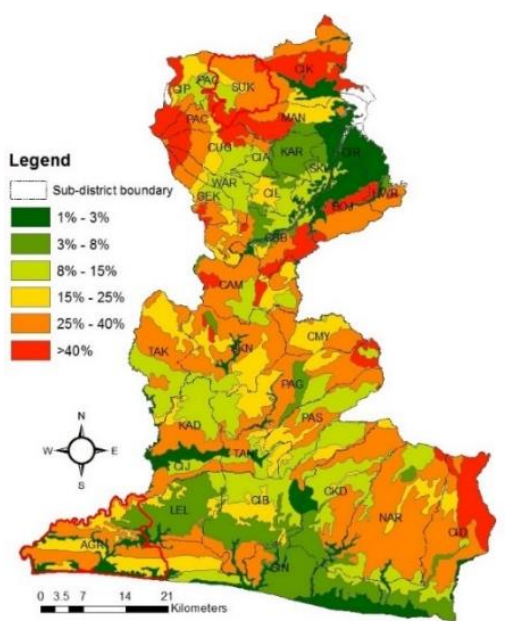

Figure 3 Slope of Cianjur

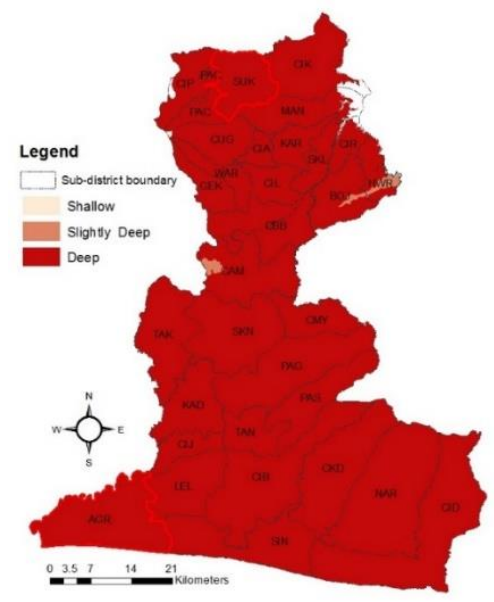

Figure 6 Solum depth of Cianjur

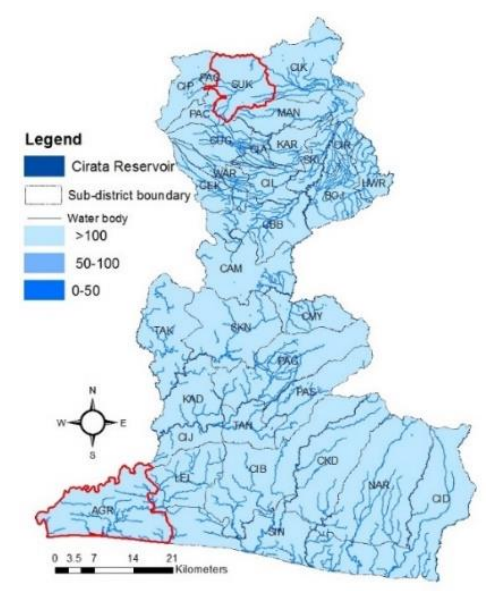

Figure 9 Distance from the river of Cianjur

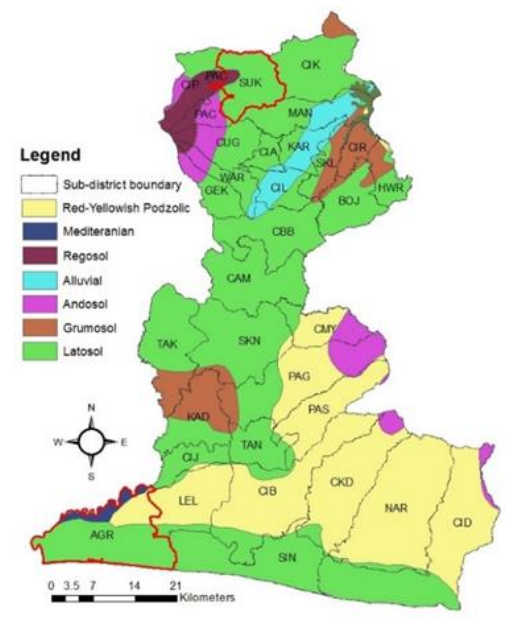

Figure 4 Soil types of Cianjur

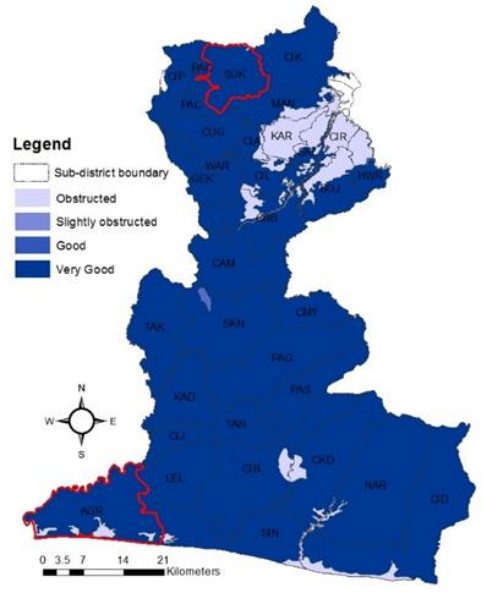

Figure 7 Drainage of Cianjur

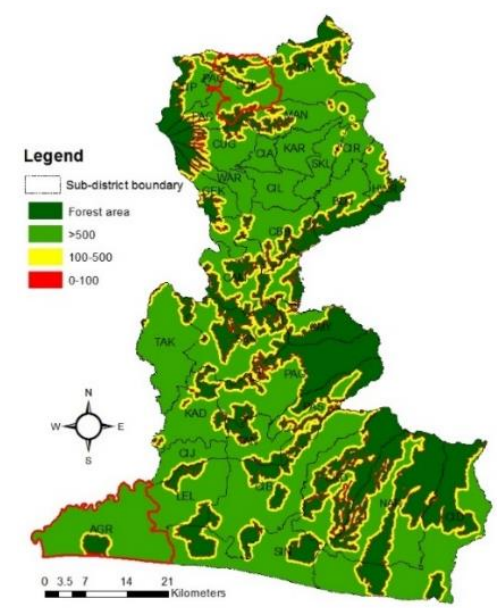

Figure 10 Distance from the forest of Cianjur

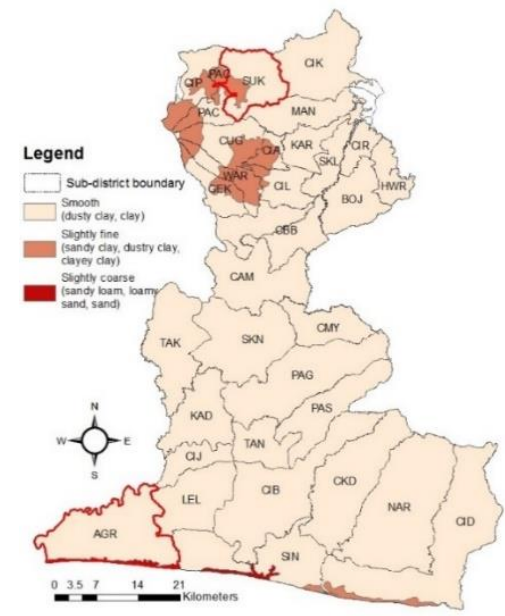

Figure 5 Soil textures of Cianjur

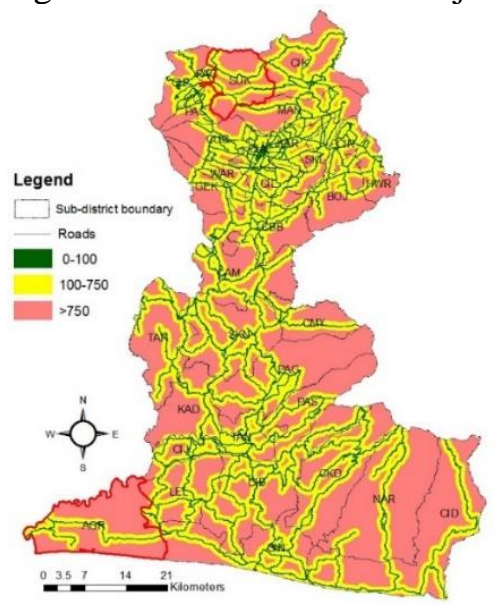

Figure 8 Distance from road of Cianjur

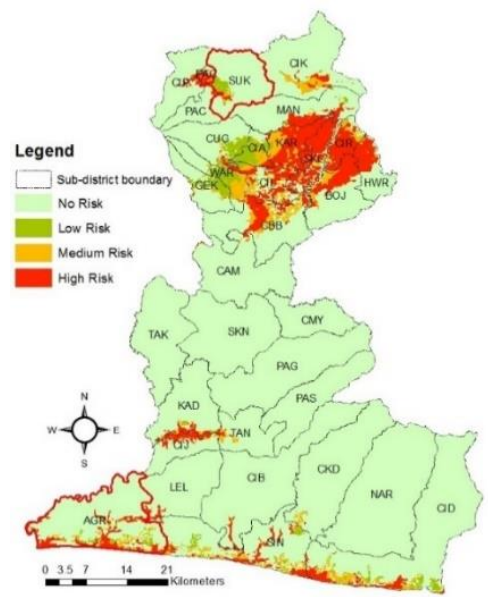

Figure 11 Distance from the river of Cianjur 


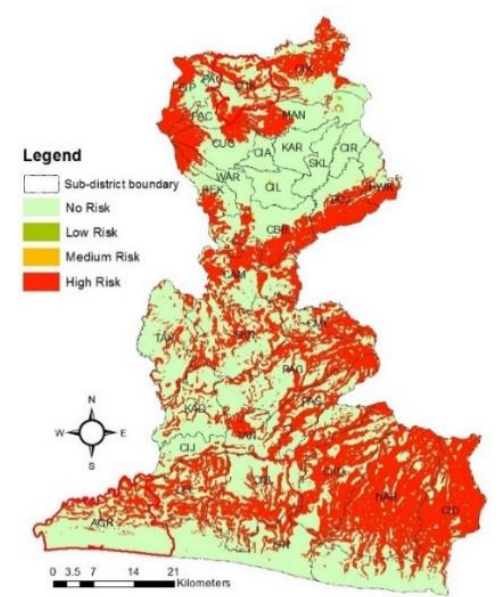

Figure 12 Landslide risk of Cianjur

Almost the same situation also found in silt and clay. It will generally be stable and able to provide sufficient shear strength and a slight tendency to change in volume. However, silt is difficult to compact when wet, due to its low permeability (Hardiyatmo, 2013). Solum depth for agriculture is that the deeper the solum, the better it is for plantation and crops to grow. For settlement uses is different. The deepest the solum, the more unsuitable it is for settlement, vice versa. The shallower the solum depth, the more relevant it is for settlement. Because the shallow solum means the foundation of the building construction can reach the soil texture's hardness easily. Therefore, the building foundation becomes more vital. Adequate solum depth affects the sensitivity of the soil to erosion. Deep and permeable soils are less susceptible to erosion than permeable but shallow soils. Solum depth and the impermeable layer determine the amount of water that can be absorbed and affecting runoff. With reduced runoff means less soil erosion. Solum area in Cianjur Regency is primarily deep. It is classified as not suitable land for settlement. Therefore, almost all the land (99.4\%) is suitable for settlement development (Figure 6).

Drainage is such an essential aspect of people's lives on their daily activity. Such drainage is often be called closed drainage. The primary function is to flow human waste. In this research, the analysis of drainage conditions referring to open drainage. The natural part of it is to flow the runoff. If the rain stays, the possibility of the flood is more substantial, especially in the city. Drainage of Cianjur Regency is mostly in excellent and good situation. Mean the $93 \%$ of the area in Cianjur regency is suitable for settlement (Figure 7). However, there are still some areas that have a problem with the drainage. Their drainage is obstructed. It classifies as an area that is not suitable for settlement development. These areas are Ciranjang, Karangtengah (Northern Cianjur) and Cidaun (Southern Cianjur).

\section{Accessibility Consideration}

Accessibility on settlement accommodates access to facilities, services, and socio-economic opportunities. It plays a critical role in the growth and decline of cities and human settlement (Hasan et al., 2017). Roads are essential for people because they connect people from one place to another. The more roads are available, the easier the activity of people is. To build the road, it is necessary to see the slope and the soil types and characteristics. The more sloping the ground is, the more suitable it is for road construction. The soil with a compact texture finds it easier to compact soil. Then the foundation of the roads becomes stronger. Therefore, the soil like mud and cohesion is not suitable for roads construction. Yet, it is impossible to build, but it is very costly. The steep slope is expensive. It is not eligible for roads. On the other hand, the ability of the transport also has a limitation.

The distance from the roads is referring to Madurika and Hemakumara (2015) and Hasan et al., (2017). The closer the built-up areas to the roads, the more suitable it is for settlement development. Result shosw 335 $\mathrm{km}^{2}$ of Cianjur has a distance 0 meters to 100 from the roads. Therefore, the suitable area for settlement 558 
development is only $9 \%$ of the total area (Figure 8). Meanwhile, the marginally and not suitable distance from road is dominant. They are $1444 \mathrm{~km}^{2}$ and $1840 \mathrm{~km}^{2}$ respectively. The sub-district which has more road is Cianjur, Cipanas and Ciranjang.

\section{Conservation Consideration}

Two sub-criteria measured the land's suitability for settlement, the distance from the river and the forest. Utilization on the river has been written in the Government Regulation of Republic Indonesia No. 38 the year 2011 about The River. A distance from the forest also has been reported in the Government Regulation of Indonesia No. 41 year 1999 about Forest.

\section{Distance from the river.}

In the northeast of Cianjur, there is a reservoir called "Cirata". This reservoir considers as the upstream. The area closer to the reservoirs has more small rivers flow in its territories, such as Ciranjang and Sukaluyu sub-districts, etc. On the other hand, the southern part is bordering the South beach. It is the downstream. The South-west connects to some rivers. Some of them are separated Cianjur Regency and Sukabumi Regency. Referring to the government regulation of Indonesia No. 38/2011 about The River and Indonesia's Constitution No. 41 about Forest, the region with a distance from the river more than 100 meters is highly suitable for settlement development. The farther to the river, the more suitable it is for the settlement development. In general, the houses built near the river will cause many problems (Subiyanto et al., 2021). Local people are disposing of the household waste in the river. It blocks the flow of the river and finally causes floods. Therefore, the closer the area to the river, the more unsuitable the space is used for settlement. The total area, which is more than 100 meters from the river, is $3124.63 \mathrm{~km}^{2}$ (Figure 9).

\section{Distance from the forest}

Regarding Indonesia's Constitution No. 41 about Forest, the primary function of the forest is three: (1) conservation; (2) protection and (production). It is forbidden to interfere with forest function. Consequently, the farther the distance from the forest area, the better it is for settlement development, and the closer to the forest, the more unsuitable it is. Therefore, the total most suitable land for settlement development with a distance more than 500 meters from the forest is $1971.71 \mathrm{~km}^{2}$. Figure 10 demonstrates the distribution of forest as a protected area and its buffer. Meanwhile, more than half area of Pagelaran, Cikadu, Naringgul are forest and conservation areas. In the Northern Cianjur, Cipanas, Pacet, Gekbrog Cugenang and Warungkondang is a protected area. It is Gede Mountain.

\section{Disaster Consideration}

Referring to the Minister of Public Works Regulations No. 24/PRT/M/2007 about Technical Guidelines for Building Permits, the settlement cannot be built on risky land from disaster, especially flood and landslide. Reserved data on this study was gathered from InaRisk of the Indonesian National Board for Disaster Management. The Risk Index presents the dangers of the disaster (Amri et al., 2016). On the InaRisk, there are three classes of the risk are High risk, Medium risk and Low risk. The area which no risk, low risk, and medium risk is considered as suitable land for settlement. Yet it distinguished by land suitability class ("highly suitable, suitable and marginally suitable"). On the other hand, the High risk class is not suitable for settlement development. Therefore, the High risk class identified with "not suitable".

\section{Flood risk}

Floods are correlated with: (1) the region with the lowland is very potential because of the difficulty of disposing of rainwater and receiving runoff from the area above it; (2) the rain intensity; (3) soil's ability on catching and the water. A cohesive (tight) soil type is not good soil for water absorption so that it can be 
exposed to puddles and; (4) types of vegetation. It is because of the ability of the plant to hold the water. Table 12 informs the area which has a risk to flood. From the Figure 11, it can be seen that majority of the areas has no flood risk $3114 \mathrm{~km}^{2}$. Meanwhile, the area with high risk and not suitable for Settlement is the area that is bordering the Cirata reservoir like Ciranjang, Karangtengah, Cilaku, and Haurwangi Sub-districts. The same situation also happening the southern Cianjur. The area that is bordering the South beach, such as Agrabinta, Sidangbarang, and Cidaun are very risky with flood. As a result, the total area with a high risk of flood is 287 $\mathrm{km}^{2}$.

\section{Landslide risk}

Landslide is related to the slope, Rain intensity, soil types, and soil textures. The layer below it in the form of impermeable soil or rock, which can become slip fields and vegetation, is very potentially affected by landslides. The majority of Cianjur Regency has a slope between $25-40 \%$, making it very vulnerable to disasters like landslides. The result shows the majority of the land in Cianjur is at no risk $\left(2043 \mathrm{~km}^{2}\right)$, which means it is suitable for settlement. Meanwhile, the area with the high risk is also significant. It reached $43 \%$ of the total area of Cianjur Regency (Figure 12).

\section{Suitability class for settlement in Cianjur}

AHP is employed to see the priorities between sub-criteria. The emphasis was the preference of the experts. There are nine experts interviewed, which represent the governments, academics, and developers. Figure 13 shows the level of importance of the sub-criteria. The result shows that the most important criteria are from disaster considerations are landslide risk and flood risk. With the weight is 0.20 and 0.14 respectively. Meanwhile, the least crucial sub-criterion is from conservation consideration. It is the distance from the river. The weight is only 0.05 . The consistency of judgment among sub-criteria is presented from the CI value. To be accepted, the consistency must be less than 0.1 . In this case, the CI value is 0.07 . Therefore, it is consistent.

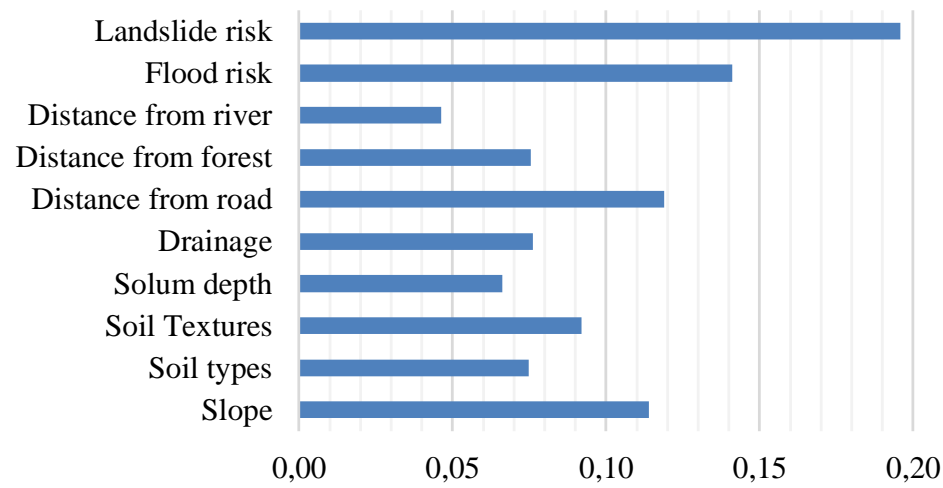

Figure 13 The weight of importance level sub-criteria

Figure 14 describes the order of sub-criteria priorities between experts. A similar trend can be seen in academics and government. The most crucial sub-criterion is landslide risk, and the second most important is flood risk. Both are from the conservation consideration. The different trend is shown from developer preferences. They think that the most important sub-criterion is the distance from the road, from the accessibility consideration. The most influential criterion on land suitability is various. A different result is shown by (Madurika dan Hemakumara, 2015) which an essential standard for land suitability for settlement in Greater Matara Region is elevation. That is proof that every region has its uniqueness and its capabilities for building the settlement. If the developer preferences are taken as a basis, the method can model the potential future expansion of housing development according to the local interest. Because developer interest often is substituted with consumer preferences. In the end, the planning can use this information for strategy building (Palmas et al., 2012). 
Governments and academics preferences disaster consideration is the most crucial is because they thing for the long-term impact and the cost might be caused by the disaster. For example, is the tangible and intangible cost. If the flood risk and flood happening there will be many people are die and injured, the building may be destroyed etc. In many occasion, all those thing becomes governments responsibilities. In contrast with the developers. If the something happening with the unit/building, the responsibility is belonging to the owner.

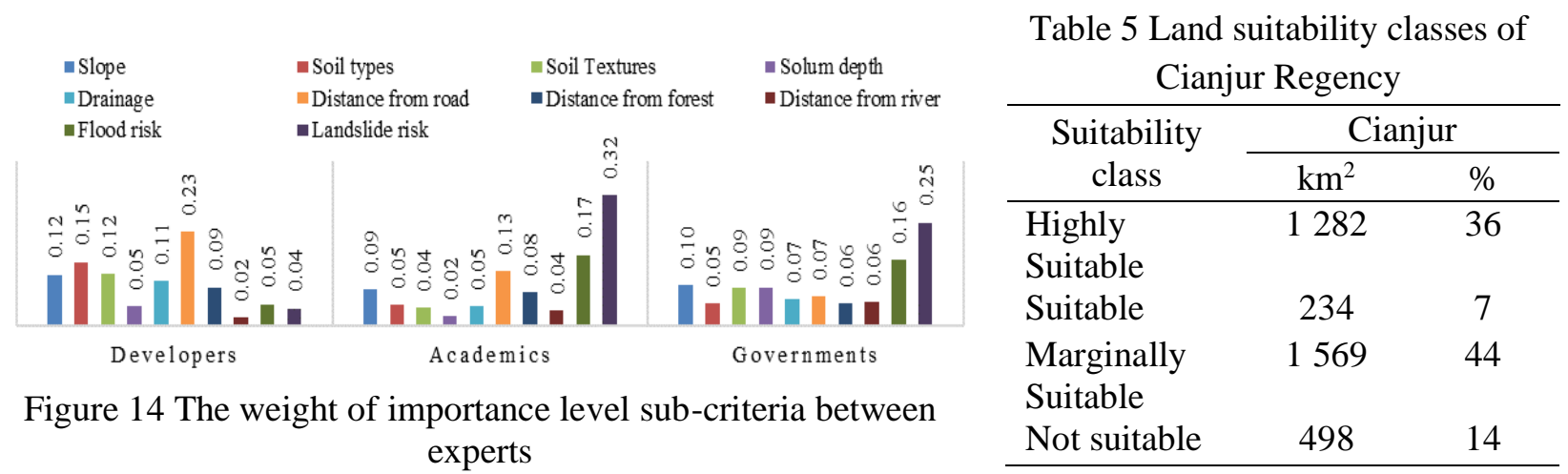

The MCE's score ranges from 122 to 339. The suitability class is divided into four classes (Figure 15), namely: (1) highly suitable class with a score is from 122 to 176; (2) suitable class with a score is from 177 to 230; (3) marginally suitable class score is from 231 to 285; and (4) Not suitable class is from 285 to 339 . The result of the land suitability analysis is shown in Table 6 . The majority of Cianjur regency is in the marginally suitable class, with a total area of $1569 \mathrm{~km}^{2}(44 \%)$.

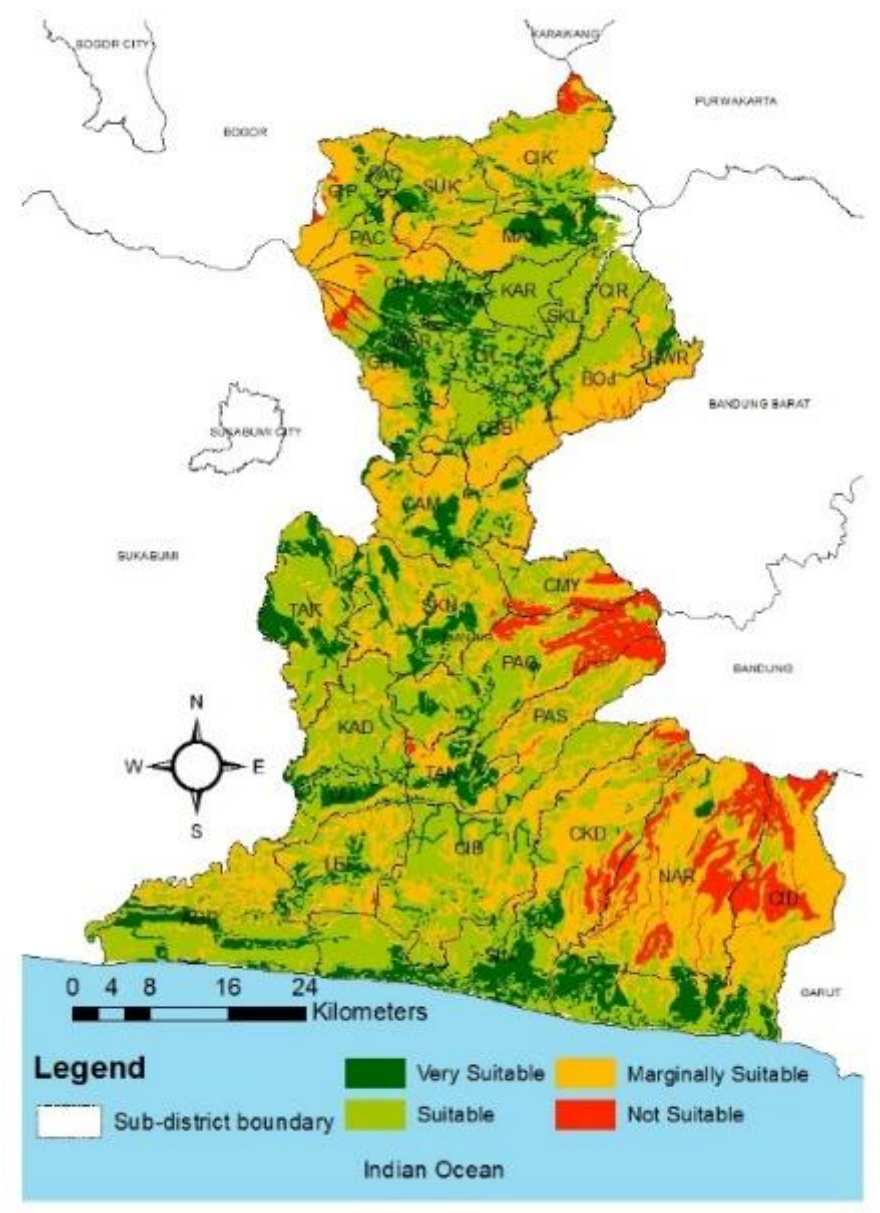

Figure 15 Land suitability class for settlement in Cianjur 
Land suitability's assessment for settlement is necessary to conduct because it gives the perspective and information to the stockholders on deciding which land is more suitable and less suitable to construct the building. The use of the suitable land decreases the environmental impacts on the development planning (Palmas et al., 2012).

\section{Land Availability for Settlement in Cianjur Regency}

\section{Available Land for Settlement in 2018}

Figure 16 (c) shows that the total available land for settlement in 2018 is $3047 \mathrm{~km}^{2}$, or $85 \%$ of the total area of Cianjur is available for settlement development in the future. Meanwhile, $534 \mathrm{~km}^{2}$, or $15 \%$ of the total area of Cianjur Regency, is not available for settlement development in the next few years. Not available land for settlement in 2018 is the land classified as the current settlement. With the assumption that the land that's has been built for settlement is not available. It is because there is no construction under the built-up areas. The rest of the land uses, such as agricultural uses, can be allocated as a settlement in the future. In this part, no regulation is implemented. Therefore, the result shows a massive amount of available land to be allocated as a settlement in 2030 .

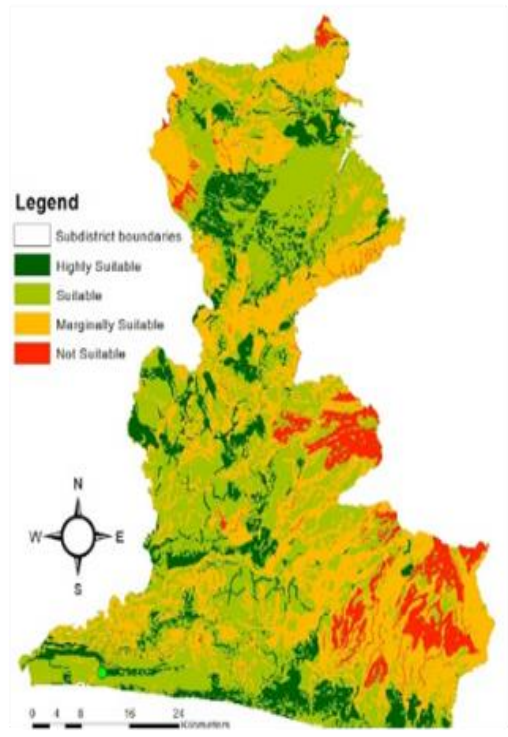

(a)

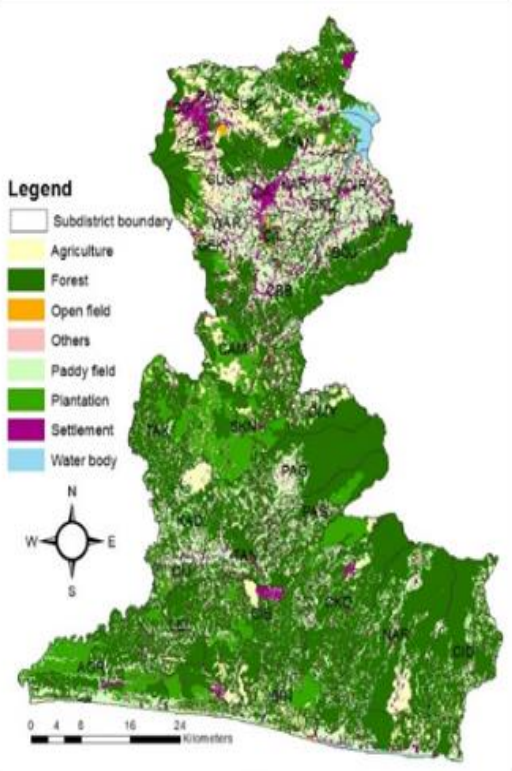

(b)

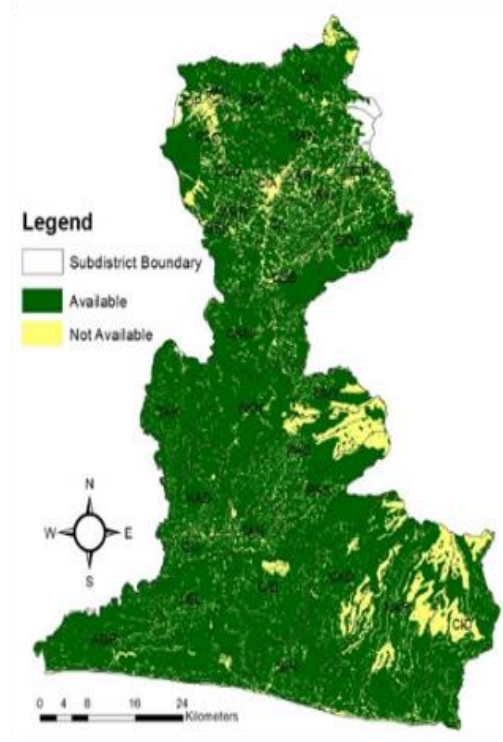

(c)

Figure 16 Thematic maps of (a) land suitability; (b) land-use 2018, and; (c) land availability in 2018

\section{Potential Available Land for Settlement in 2030}

Potential available land in Cianjur Regency is only 4\% (Figure 17) of the total area, nearly $131 \mathrm{~km}^{2}$, which means $96 \%$ or $3450 \mathrm{~km}^{2}$ of the total area is not available for settlement in 2030 . The use of the spatial plan as a limiting factor affects land availability massively. It means that the land allocation of another use other than a settlement is not allowed to be used as a settlement in the future. Such planning is the suit planning among planers. Because on many occasions, the planner did not see spatial regulation to obey. But if they did, they tend to do not care about the regulation. They allow the spatial plan to follow the development in the region.

That situation often caused the problem socially, environmentally, and economically. For example, is the planning on the boundary districts of Bogor, Bekasi, Depok, and Tangerang, research by (Mulya et al., 2018) and deviates planning from spatial plan (Astika et al., 2021). The use of Spatial Planning as the limiting factor for settlement in Cianjur Regency can minimize the problem, specifically land conversion for better planning. 


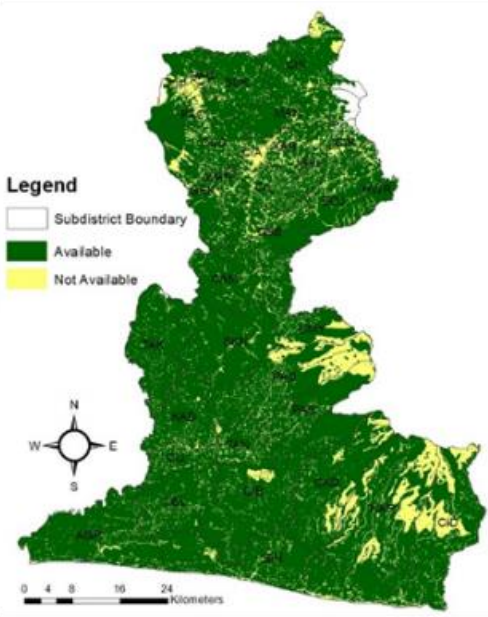

(a)

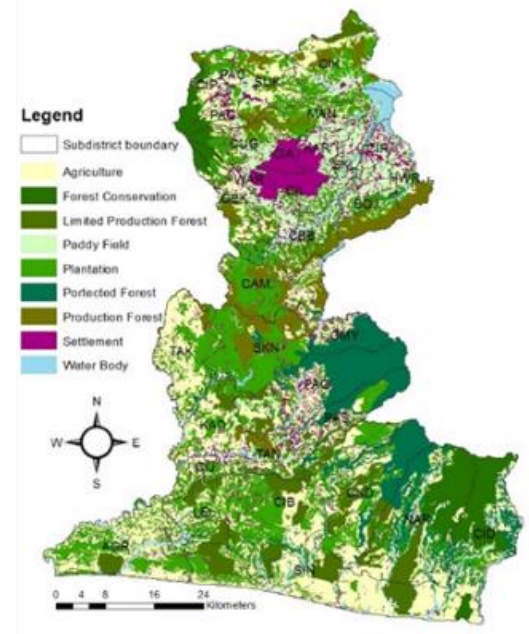

(b)

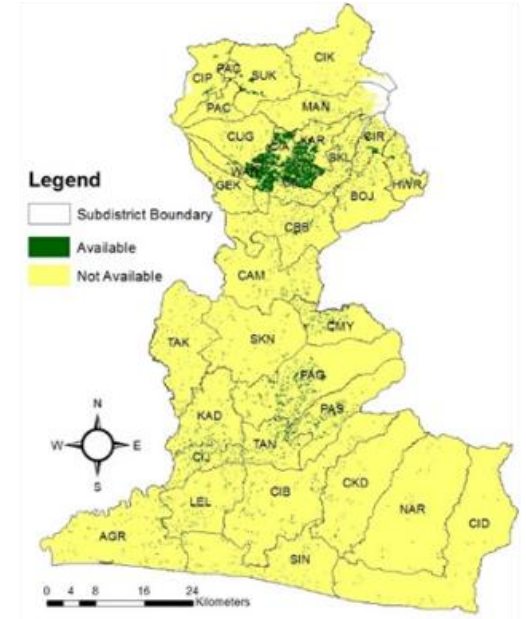

(c)

Figure 16 Thematic maps of (a) land availability in 2018; (b) spatial plan and; (c) potential available land in 2030

\section{Land Availability for Settlement in 2030}

The land availability in 2030 is used LP2B as the limiting factor. It is intended to obey Indonesia's Constitution No. 41 Year 2009 about Sustainable Food Agriculture Land Protection or in Bahasa is Lahan Pertanian Pangan Berkelanjutan (LP2B). The constitution then regulates on the region level, in this case on the Local Regulation of Cianjur Regency No 4 Year 2019 about Sustainable Food Agriculture Land Protection. Figure 18 shows there is a decrease amount of land potential available in 2030 around $2 \%$. The available land for settlement development in the future is only $81 \mathrm{~km}^{2}$ (Figure 18). The rest of it is not available for settlement development. The use of LP2B as the limiting factor can minimize the land conversion on the paddy field. It benefits Cianjur from agricultural perspective. To achieve food security every planning has to consider LP2B. Therefore, expectantly all the regions will issue the LP2B regulation soon. If not, the paddy field will be converted to built-up areas (Ricky et al., 2017; Firmansyah et al., 2018).

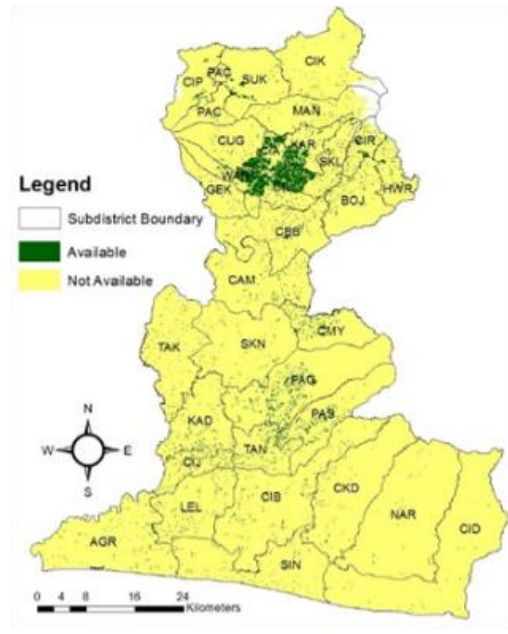

(a)

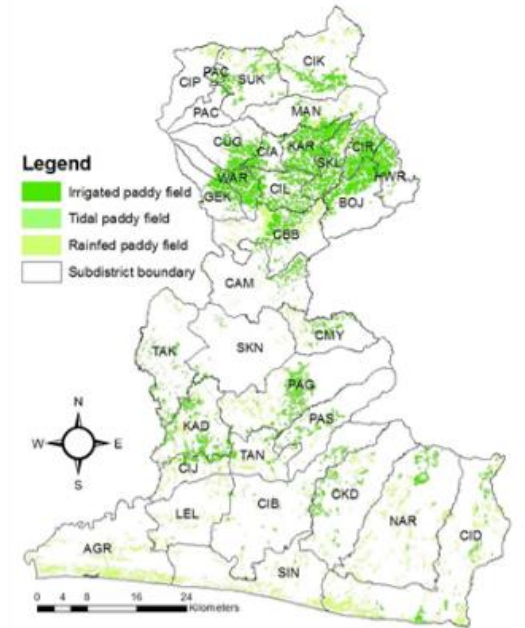

(b)

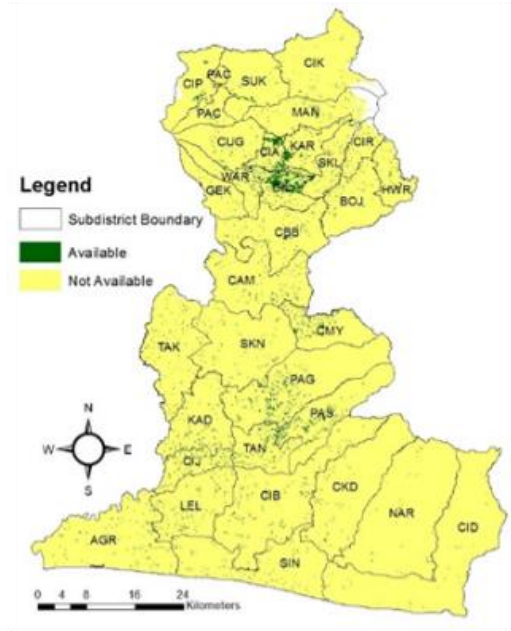

(c)

Figure 17 Thematic maps of (a) potential available land in 2030; (b) LP2B, and (c) land availability in 2030

\section{Land Availability comparisons for Settlement in 2030}

Figure 19 explains the comparison between land availability analyses. The available land for settlement is decreasing on every step. When overlapping the suitability map with the land-use map, the available land for settlement is high. It reaches more than $3000 \mathrm{~km}^{2}$. That is because no regulation is implemented. By means, 
any land use in 2018 can to be used as the settlement use. When it comes to the available land in 2030, a massive decrease in the available land is found. The available land for settlement in 2030 becomes only 131 $\mathrm{km}^{2}$. That is because of the implementation of local regulation of Spatial Plan of Cianjur Regency No. 17 Year 2012. Spatial Plan arranges the use of land for Cianjur Regency from 2011 until 2030. Therefore, the land demand for settlement in Cianjur Regency can be allocated only on the land designated for settlement uses.

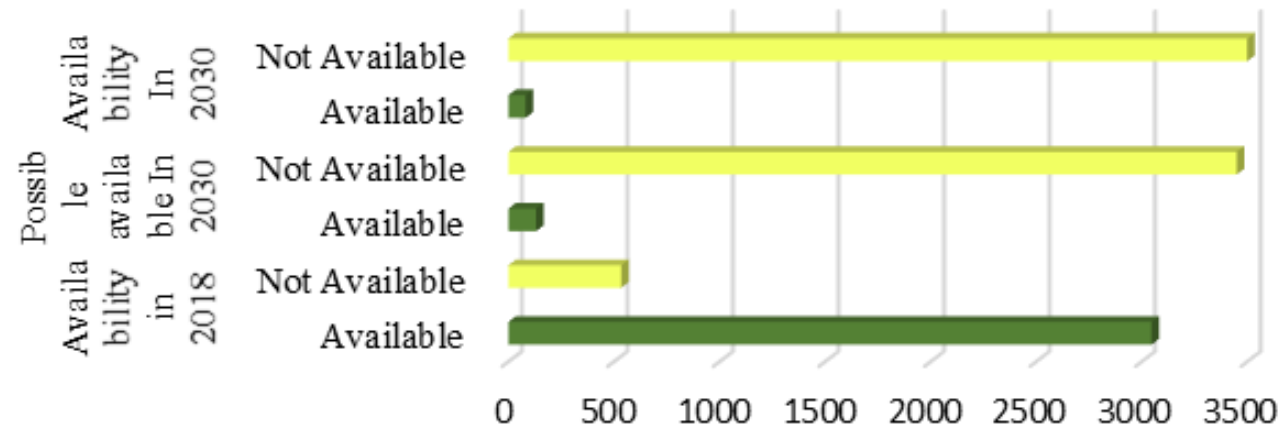

Figure 18 Land availability comparisons $\left(\mathrm{km}^{2}\right)$

The recent regulation has come out on the restriction of Sustainable food farms, which is set on the local law of Cianjur Regency No. 4 Year 2019 about Sustainable food farms (LP2B). This regulation prohibits the LP2Bland use or conversion to other services except for rice fields. Therefore, on the land allocation process, LP2B also has to consider. As a result, the area of available land for settlement decreasing again. Now it has become only $81 \mathrm{~km}^{2}$. There is an unmatched use between Spatial Plan and LP2B. Apparently, because of the issuance of LP2B, the settlement directives on Spatial Plan are no longer appropriate. Therefore, changes are needed to the spatial plan of Cianjur Regency, to synchronize between LP2B and future land use plans.

\section{CONCLUSION}

Land suitability for settlement in Cianjur Regency is dominantly marginally suitable (44\%). Therefore, building the settlement in a marginally suitable class is might be expensive and difficult. It is because the land has to be repaired first. The different perspectives among developers, academics, and government in determining the most critical criteria for land suitability plays a crucial role in the next Cianjur's development planning.

Land availability for settlement in Cianjur Regency in 2030 is only $81 \mathrm{~km}^{2}$, just $2 \%$ of the total area. It means that the suitability analysis is not enough for defining the land for settlement. Because the suitable land is not necessarily available. In addition, by implementating the Spatial Plan and LP2B as the limiting factors, the land availability for settlement is relatively small. Yet, the planning is in line with the regulations. In such situation, no other use of land will be disturbed and the number of problems will be decreased.

\section{REFERENCES}

[BPS] Badan Pusat Statistik. 2019. Kabupaten Cianjur Dalam Angka 2019. Kabupaten Cianjur (ID): Badan Pusat Statistik Kabupaten Cianjur.

Amri MR, Gita Y, Ridawan Y, Sesa W, Asfirmanto WA, Ageng NI, Roling ER, Rizky TS. 2016. Risiko Bencana Indonesia (Disasters Risk of Indonesia). Raditya J, Robi AM, editor. Jakarta (ID): Direktorat Badan Nasional Penanggulangan Bencana.

Asfari A, Rizqihandari N, Geografi D, Matematika F, Alam P, Indonesia U, Kunci K. 2017. Model dinamika spasial hubungan pertumbuhan penduduk dengan ketersediaan lahan di Kabupaten Cianjur bagian Utara, Provinsi Jawa Barat. Pros Industrial Research Workshop and National Seminar; 2017 Jul 26-27; Bandung, Indonesia. Bandung (ID): Politeknik Negeri Bandung. p 254-260. 
Asoka NGW, Thuo ADM, Bunyasi MM. 2013. Effects of population growth on urban infrastructure and services: A case of eastleigh neighborhood nairobi, Kenya. J Anthropol Archaeol. 1(1): 41-56.

Astika IWD, Arnawa IK. Sukerta IM, Indrawati IGAPT. 2021. Factual development of constructed land in. International Journal of Sustainability, Education, and Global Creative Economic. 4(2): 119-127.

Bupati Cianjur. 2019. Peraturan Daerah No. 4 Tahun 2019 Tentang Lahan Pertanian Pangan Berkelanjutan. Cianjur (ID): Bupati Cianjur Regency.

Bupati Cianjur. 2012. Peraturan Kbaupaten Cianjur No. 17 Thaun 2012 Tentang Rencana Tata Ruang Kabupaten Cianjur Tahun 2011-2031. Cianjur (ID): Bupati Cianjur Refgency.

Chairunnisa C, Munibah K, Widiatmaka. 2017. Land use change and land expansion potency for paddy field in Cianjur Regency. Jurnal Ilmu Tanah dan Lingkungan. 19: 33-40.

Firmansyah F, Pratomoatmojo NA, Kurniawati UF, Susetyo C, Pamungkas A, Idajati H. 2018. Sustainable agricultural land use determination modelling in Banyuwangi. IOP Conference Series Earth Environmental Science. 202(1): 1-7. doi: 10.1088/1755-1315/202/1/012046.

Gayen A, Saha S. 2018. Deforestation probable area predicted by logistic regression in Pathro River Basin: A tributary of Ajay river. Spatatial Information Research. 26(1): 1-9. doi: 10.1007/s41324-017-0151-1.

Harahap FR. 2013. Dampak urbanisasi bagi perkembangan kota Di Indonesia. Society. 1(1): 35-45. doi: 10.33019/society.v1i1.40.

Hardiyatmo HC. 2013. Stabilitas Tanah untuk Pekerjaan Jalan. Edisi kedua. Yogyakarta (ID): Gadjah Mada University Press.

Hasan S, Wang X, Khoo YB, Foliente G. 2017. Accessibility and socio-economic development of human settlements. PLoS One. 12(6): 1-16. doi: 10.1371/journal.pone.0179620.

Hudalah D, Nurrahma V, Sofhani TF, Salim WA. 2019. Connecting fragmented enclaves through network? Managing industrial parks in the Jakarta-Bandung Urban Corridor. Cities. 88: 1-9. doi: 10.1016/j.cities.2019.01.005.

Ingram GK. 2014. Defining Metropolitan and Megapolitan Areas. Beijing (CN): Lincoln Institute of Land Polic.

Isao I, Hemanta H. 2011. Soil Mechanics Fundamentals. New York (US): Taylor \& Francis.

Kadriansari R, Subiyanto S, Sudarsono B. 2017. Analisis kesesuaian lahan permukiman dengan data citra resolusi menengah menggunakan sistem informasi geografis. Jurnal Geodesi Undip. 6: 199-207.

Madurika H, Hemakumara G. 2015. Gis based analysis for suitability location finding in the residential development areas of greater matara region. International Journal of Science and Technology Research. 4(8): 96-105.

Mulya SP, Rustiadi E, Pravitasari AE. 2018. Land use and spatial planning in the boundary's district/city. Proceeding The $9^{\text {th }}$ International Conference of Rural research and Planning Group; 2018 Jul 6-8; Bali, Indonesia. Denpasar (ID): Universitas Mahasarasawat. p 122-134.

Palmas C, Abis E, Haaren C Von, Lovett A. 2012. Renewables in residential development: An integrated GISbased multicriteria approach for decentralized micro-renewable energy production in new settlement development: A case study of the eastern metropolitan area of Cagliari, Sardinia, Italy. Energy, Sustainability and Society.2(10): 1-15.

Panuju DR. 2016. Teknik-Teknik untuk Proses Pengambilan Keputusan. Bogor (ID): IPB University.

Ricky, Rustiadi E, Barus B. 2017. A projection of land needed for settlements and conversion of paddy fields in solok city. Journal Regional City and Planning. 28(3): 186-203. doi: 10.5614/jrcp.2017.28.3.3.

Rustiadi E, Pravitasari AE, Setiawan Y, Mulya SP, Pribadi DO, Tsutsumida N. 2021. Impact of continuous Jakarta megacity urban expansion on the formation of the Jakarta-Bandung conurbation over the rice farm regions. Cities. 111: 1-19. doi: 10.1016/j.cities.2020.103000.

Ruswandi A, Rustiadi E, Mudikdjo K. 2007. Dampak konversi lahan pertanian terhadap kesejahteraan petani dan perkembangan wilayah: Studi kasus di daerah Bandung Utara. Journal Agro Ekonnomy. 25(2): 207219. doi: 10.21082/jae.v25n2.2007.207-219. 
Saaty RW. 1987. The analytic hierarchy process-what it is and how it is used. Math Model. 9(3-5): 161-176. doi: 10.1016/0270-0255(87)90473-8.

Saaty TL. 2008. Decision making with the analytic hierarchy process. International Journal Services Science. 1(1): 83-98. doi: 10.1504/IJSSCI.2008.017590.

Sadyohutomo M. 2009. Manajemen Kota dan Wilayah Realita dan Tantangan. Jakarta (ID): Bumi Aksara.

Steinberg F. 2014. Rural-Urban Linkages : An Urban Perspective. Working Paper Series $N^{\circ} 128$. Working Group: Development with Territorial Cohesion. Santiago (CL): Rimisp.

Subiyanto S, Amarrohman FJ, Rahmah AN. 2021. Modeling changes in land use using the integration of MLPNN, CA-Markov models and GIS for settlement development in Tembalang District. IOP Conference Series Earth Environ Sci. 731(1): halaman. doi: 10.1088/1755-1315/731/1/012026.

Tanjung NA, Hoshino S, Onitsuka K, Basu M, Sianipar PM, Rustiadi E. 2021. Developing a system dynamics model to predict the impacts of urban expansion on land-use change in Cianjur Regency, Indonesia [thesis]. Japan (JP): Kyoto University.

Umar I, Widiatmaka, Pramudya B, Barus B. 2017. Evaluation for suitability land of settletment area by using multi criteria evaluation method in Padang. Journal of Natural Resources and Environmental Management. 7(2): 148-154. 